\title{
INCREASE INCOME AND MORTALITY OF COLORRECTAL CANCER IN BRAZIL, 2001-2009
}

\author{
Raphael Mendonça GUIMARÃES'1, Paulo Guilherme Molica ROCHA², \\ Camila Drumind MUZI ${ }^{3}$ and Raquel de Souza RAMOS 3
}

\begin{abstract}
Context - Several international studies have observed a correlation between the improvement of socio-demographic indicators and rates of incidence and mortality from cancer of the colon and rectum. Objective - The objective of this study is to estimate the correlation between average per capita income and the rate of colorectal cancer mortality in Brazil between 2001 and 2009. Methods - We obtained data on income inequality (Gini index), population with low incomes ( $1 \frac{2}{2}$ infer the minimum wage/ month), average family income, per capita ICP and mortality from colon cancer and straight between 2001-2009 by DATASUS. A trend analysis was performed using linear regression, and correlation between variables by Pearson's correlation coefficient. Results - There was a declining trend in poverty and income inequality, and growth in ICP per capita and median family income and standardized mortality rate for colorectal cancer in Brazil. There was also strong positive correlation between mortality from this site of cancer and inequality (men $\mathrm{r}=-0.30, P=0.06$, women $\mathrm{r}=-0.33, P=0.05$ ) income low income (men $\mathrm{r}=-0.80, P<0.001$, women $\mathrm{r}=-0.76, P<0.001)$, median family income (men $\mathrm{r}=0.79, P=0.06$, women $\mathrm{r}=0.76, P<0.001)$ and $\mathrm{ICP}$ per capita $(\mathrm{men} \mathrm{r}=0.73$, $P<0.001$, women $\mathrm{r}=0.68, P<0.001$ ) throughout the study period. Conclusion - The increase of income and reducing inequality may partially explain the increased occurrence of colorectal cancer and this is possibly due to differential access to food recognized as a risk factor, such as red meat and high in fat. It is important therefore to assess the priority of public health programs addressing nutrition in countries of intermediate economy, as is the case of Brazil.
\end{abstract}

HEADINGS - Colorectal neoplasms, mortality. Poverty.

\section{INTRODUCTION}

The colorectal cancer (CRC) comprises malignant tumors located in the large intestine formed by the colon (located in the abdomen) and the rectum (located in the pelvis) ${ }^{(2,26)}$. The incidence and mortality of CRC have shown, worldwide, an increasing trend, especially in the developed countries and urban areas of developing countries. Worldwide, CRC is the fourth most incident ${ }^{(9)}$ neoplasm and constitutes a potentially curable disease when diagnosed in early stages. The survival of the CRC is considered good if diagnosed early, with a 5-year average survival between $40 \%$ and $50 \%$, and there were no major differences between developed and developing countries. This relatively good prognosis makes the CRC is the second most prevalent cancer worldwide totaling approximately 2.4 million people living with this cancer ${ }^{(15)}$.

In Brazil, the CRC are among the five most common locations of cancer in both sexes ${ }^{(6)}$. Is the third most frequent cancer (excluding non-melanoma skin tumors), with an estimated 28,110 new cases in 2010 (with 13,310 cases in men and 14,800 in women). Cancer of the colon and rectum in men is the third most common in the South $(21 / 100.000)$ and Southeast (19/100.000), while in the Midwest ranks fourth $(11 / 100.000)$ and in the Northeast $(5 / 100.000)$ and North (4/100.000) is the fifth most commonly diagnosed malignant type. For women, it is the second most common in the South $(22 / 100.000)$ and Southeast (21/100.000), the third in the Midwest $(11 / 100.000)$ and Northeast (6/100.000) and fifth in the North $(4 / 100.000)^{(13)}$.

The recent increase in the incidence of CRC in Brazil is due to longer life expectancy, combined with dietary changes of the population. We know that $\mathrm{CRC}$ is much more common in individuals over 50 years, with an exponential increase in the number of diagnoses from this age ${ }^{(23)}$.

The epidemiological distribution of cancer in Brazil suggests a transition in progress, with the increase in the types of cancer usually associated with higher socioeconomic status (breast, prostate and colorectal) and, at the same time, the presence of high incidence coefficients of tumors usually related to poverty (cervical cancer, penis, oral cavity and stomach) $)^{(1,10,11)}$.

Declared conflict of interest of all authors: none

IInstituto de Estudos em Saúde Coletiva/UFRJ; '2Faculdade de Medicina/UFRJ: ${ }^{3}$ nnstituto Nacional do Câncer/INCa, Rio de Janeiro, RJ, Brazil.

Correspondence: Dr. Raphael Mendonça Guimarães - Avenida Horácio Macedo, S/N - Próximo a Prefeitura Universitária da UFRJ Ilha do Fundão - Cidade Universitária. 21941-598 - Rio de Janeiro, RJ, Brasil. E-mail: raphael@iesc.ufr..br 
This epidemiological transition certainly results from exposure to various environmental risk factors related to the industrialization process (chemical, physical and biological) exposure and other factors related to social inequalities. CRC is a good example of the influence that environmental factors exert in the pathogenesis of cancer.

The mortality studies have been widely used to describe the distribution patterns of cancer, allowing the assessment of trends and correlations between observed patterns and environmental factors. Therefore, the objective of this study is to estimate the correlation between income per capita and the average mortality rate for colorectal cancer in Brazil between 2001 and 2009.

\section{METHODOLOGY}

\section{Study design}

We used the time series of mortality rates for colorectal cancer in the years between 2001 and 2009, for which data were provided by DATASUS ${ }^{(3)}$. To do the analyzes were included codes for colon and rectal cancer: C18 (malignant neoplasm of colon), C19 (malignant neoplasm of rectosigmoid), C20 (malignant neoplasm of rectum).

The specific mortality rates and age-adjusted per 100.000 men and women were calculated for each year between 1980 and 2009. Rates were calculated for specific age ranges, using intervals of 5 years from the age of 20. Mortality rates were adjusted based on the world standard population for global comparisons as proposed by Segi et al. ${ }^{(21)}$ and modified by Doll et al. ${ }^{(7)}$.

\section{Socioeconomic indicators}

Some socioeconomic indicators were used to analyze the relationship that they had with the cancer mortality colorretal $^{(3) \text { : }}$

- Internal crude product (ICP) per capita: average value added per person, in cash and the market prices of final goods and services produced in a given geographical area, the current year;

- Average income per household capita: is the average per capita household income of people living in a given geographical area, the current year;

- Gini Index: measures the degree of concentration of the distribution of per capita household income and a population in a given geographic area;

- Adults with family income $<1 / 2$ minimum wage: proportion of population with per capita monthly household income of up to half the minimum wage in a given geographic area, the current year;

\section{Data analysis}

Initially, we made the scatter diagrams between mortality rates and years of study, to evaluate the type of relationship between them. Then started the modeling process, considering mortality rates as the dependent variable $(\mathrm{Y})$ and the years of study as an independent variable (X). To study the trend, we chose to estimate regression models ${ }^{(16)}$. A trend line represents a trend, the long-term movement in time series data after other components have been accounted for. It tells whether a particular data set have increased or decreased over the period of time. A trend line could simply be drawn by eye through a set of data points, but more properly their position and slope is calculated using statistical techniques like linear regression. Trend lines typically are straight lines, although some variations use higher degree polynomials depending on the degree of curvature desired in the line. To avoid colinearity between the terms of the regression equation, we used the centralized variable.

The first model to be tested was the linear model $\left(Y=\beta_{0}+\right.$ $\left.\beta_{1} X\right)$ and subsequently tested models of higher order: second degree or parabolic $\left(\mathrm{Y}=\beta_{0}+\beta_{1} \mathrm{X}+\beta_{2} \mathrm{X}_{2}\right)$ third degree $(\mathrm{Y}=$ $\left.\beta_{0}++\beta_{1} X+\beta_{2} X_{2}+\beta_{3} X_{3}\right)$ and exponential $\left(Y=+e^{\beta}{ }_{0}+\beta_{1} X\right)$.

It was considered as the best model the one that presented the highest coefficient of determination (R2) in conjunction with the statistical significance (lowest $P$ value). When two models were similar, from the statistical point of view, to the same location, we opted for the simplest model, i.e, the lower order. A trend was considered significant one whose estimated model obtained $P<0.05$.

Finally, to assess the correlation between the rate of colorectal cancer mortality and socioeconomic indicators used across states, we carried out a bivariate analysis using Pearson's correlation coefficient. the Pearson correlation coefficient is a measure of the correlation (linear dependence) between two variables $\mathrm{X}$ and $\mathrm{Y}$, giving a value between +1 and -1 inclusive. It is widely used in the sciences as a measure of the strength of linear dependence between two variables. It was developed by Karl Pearson from a related idea introduced by Francis Galton in the 1880s.

\section{RESULTS}

Figure 1 shows the time series of indicators of income in Brazil (average income per capita and ICP per capita) between 2001-2009. Thus, it refers to the trend between 2001 and 2009, the increase in average per capita income and the rate of ICP per capita.

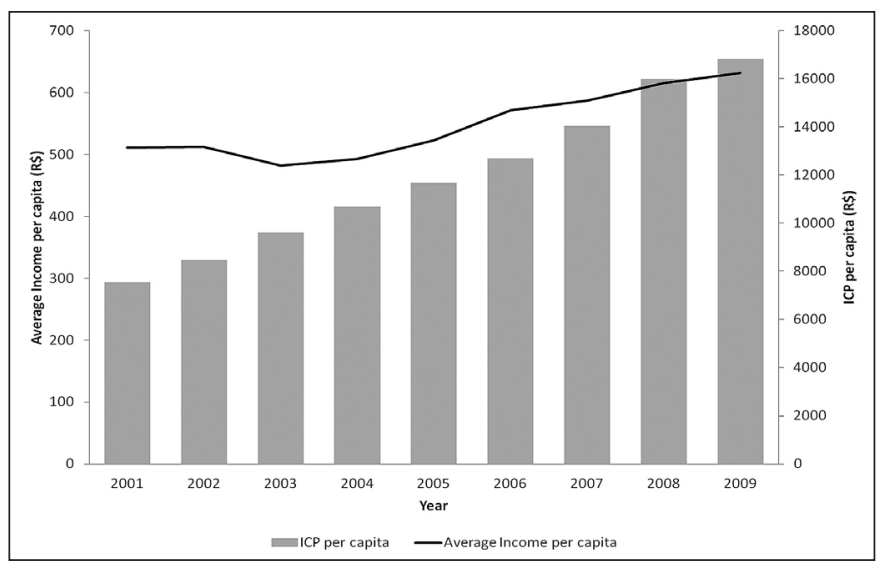

FIGURE 1. Income indicators trend in Brazil. (Per capita average income and ICP per capita). Brazil, 2001-2009 
It was observed therefore an annual increase in the average income per capita and ICP per capita. Figure 2 refers to the series of indicators of poverty and inequality in Brazil (Gini index and population with income $<1 / 2$ minimum wage/ month) between 2001-2009. Soon, relates the percentage of the population living on less than half the minimum wage per month and the Gini index, from 2001 to 2009.

Note that there was a decrease of the population living on less than half the minimum wage per month, as well as a decrease in inequality during the study period.

The Figure 3 refers trend of mortality from colorectal cancer by sex in Brazil between 2001-2009.

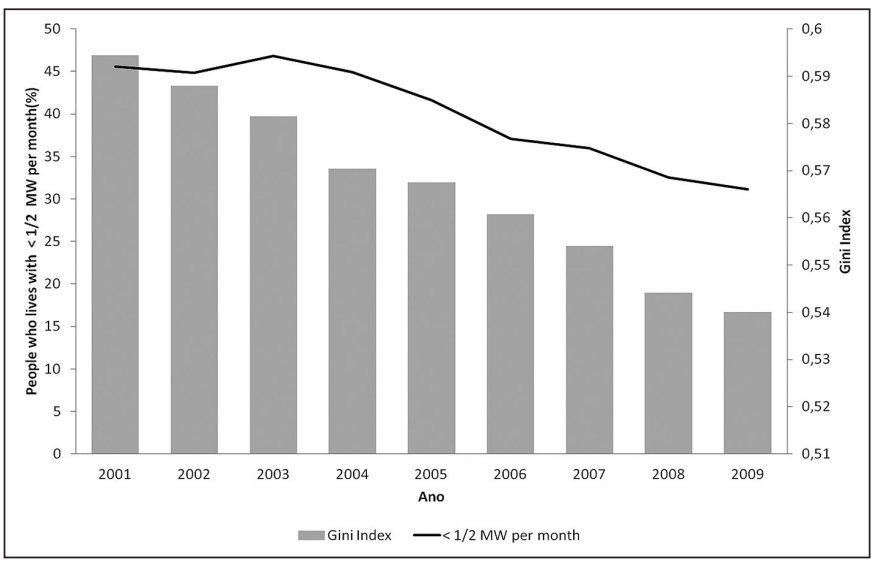

FIGURE 2. Poverty and inequalities indicators in Brazil (Gini Index and populations with income lower than $1 / 2$ minimum wage/month). Brazil, 2001-2009

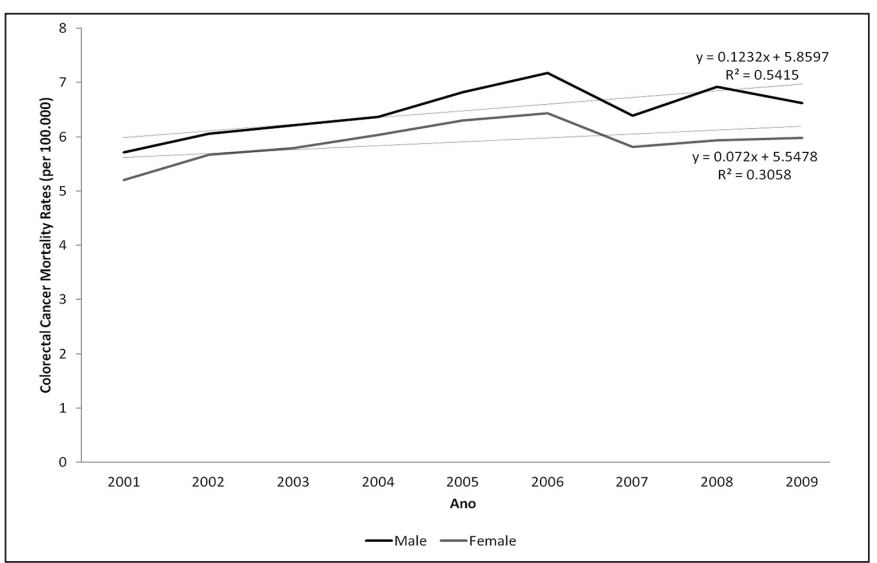

FIGURE 3. Temporal trend of colorectal mortality rates in Brazil according to sex. Brazil, 2001-2009
We can observe a linear increase for both sexes in the period analyzed and a mortality rate greater for males. Finally, Table 1 presents the correlation coefficients between socioeconomic indicators and mortality from colorectal cancer in Brazil, 2001-2009, seeking to relate the mortality rate for colorectal cancer in both men and women, with the Gini coefficient, the percentage population living on less than half the minimum wage per month, per capita income and ICP per capita through the Pearson correlation coefficient (r) and $P$ value.

Thus, we find that the mortality rate for colorectal cancer is directly related to the average income per capita and ICP per capita and an inverse relationship with the Gini index and percentage of population living on less than half the minimum wage per month, for both sexes. The $P$ value indicates that such relationships are statistically significant, with only borderline statistical significance compared to the mortality rate for CRC in men, and the Gini Index.

By observing the graphs together 1, 2 and 3 we conclude that the progressive increase in recent years the mortality rate for CRC follows the socioeconomic development of the study population, for both sexes.

\section{DISCUSSION}

In this study it is possible to note the relationship between mortality rate for cancer of the colon and rectum in Brazil, over 9 years, and socioeconomic indicators.

The association between socioeconomic status and colon cancer was investigated in a prospective cohort study initiated in 1986 in the Netherlands among 120,852 men and women aged 55-69 years. After 3.3 years of follow-up, 312 incident cases of colon cancer were detected: 157 men and 155 women. After adjustment for age, we found a positive association between the risk of colon cancer and higher education level $(P$ trend $=0.13)$ and social status $(P$ trend $=0.008)$ for men. Only the significant association between social position and the risk of colon cancer persisted after further adjustment for other risk factors for colon cancer $(P=0.005)$, but the highest risk was found only in the highest social status (RR $=2.60,95 \%$ CI 1.31 to 5.14 ). In women, there were no clear associations between indicators of socioeconomic status and colorectal cancer ${ }^{(25)}$.

Italian study did combination of two hospital-based case-control studies conducted in six Italian centers between 1985 and 1996 found that, compared with individuals with less than 7 years of education, the odds ratio for colon

TABLE 1. Correlation between socioeconomic indicators and CRC mortality rates in Brazil. Brazil, 2001-2009

\begin{tabular}{|c|c|c|c|c|c|c|}
\hline Rate & Sex & Statistics & Gini Index & $\begin{array}{l}\% \text { who lives with } \\
<\text { than } 1 / 2 \mathrm{MW} / \text { month }\end{array}$ & $\begin{array}{l}\text { Average income } \\
\text { per capita }\end{array}$ & $\begin{array}{l}\text { ICP per } \\
\text { capita }\end{array}$ \\
\hline \multirow{4}{*}{ Colorectal Rate } & \multirow{2}{*}{ Male } & $\mathrm{R}$ (Pearson)* & -0.303 & -0.805 & 0.787 & 0.730 \\
\hline & & $\mathrm{P}$ value & 0.062 & $<0.001$ & $<0.001$ & $<0.001$ \\
\hline & \multirow{2}{*}{ Female } & $\mathrm{R}$ (Pearson)* & -0.329 & -0.761 & 0.712 & 0.683 \\
\hline & & $\mathrm{P}$ value & 0.047 & $<0.001$ & $<0.001$ & $<0.001$ \\
\hline
\end{tabular}

* R (Pearson): Pearson correlation coefficient ( $\mathrm{r}$ )

$\mathrm{MW}=$ minimun average 
cancer of the colon for those with $>$ or $=16$ years was 2.45 (95\% CI 1.87 to 3.23$)$ in men and 1.29 (95\% CI 0.88 to $1.90)$ in women, with significant trends in risk. However, no significant association emerged between education and the risk of rectal cancer, with an OR of $1.18(95 \% \mathrm{CI}: 0.83$ to $1.70)$ and 1.01 (95\% CI: 0.61 to 1.67$)$, respectively, for men and women in the highest educational category compared with the lowest. Social class was also related to risk of colon cancer: the OR was 2.30 (95\% CI: 1.82 to 2.90$)$ in men and 1.33 (95\% CI: 1.03 to 1.73 ) in women in the highest versus the lowest social class ${ }^{(22)}$.

Note that the increase in TME accompanies the increase in average household income per capita of the population. It is known that the Brazilian population with higher income have different feeding habits of polluting lower risk for CRC. That consume diets high in red meat, processed meat and low in fiber, foods, while the low-income population consumes more vegetables, grains and fibers, i.e., cheap food and healthier.

Controversially, some developed countries in relation to socioeconomic status and mortality rates for colorectal cancer is reversed. This is because of poor nutrition be practiced by people of lower income, while the higher income have access to healthier foods. However, when analyzing the population of these countries, with their socioeconomic inequalities, racial/ethnic differences and uneven distribution of health care, it is noted that the incidence of CRC and therefore TME also provides an heterogeneous distribution ${ }^{(9,14)}$.

It is known that poor diet is a strong environmental factor for the development of CRC and, in Brazil, this diet low in vegetables and high in preservatives is more consumed by people of higher socioeconomic status. The opposite occurs with the poorest consumers of cheaper and healthy food ${ }^{(10)}$. In developed countries food habits also accompany socioeconomic status, allowing access of the population with higher purchasing power with higher food costs and more healthy. However, U.S. studies have shown that poor populations have high mortality rates and shorter survival for CRC. This fact is associated with a model of residual protection of health, in which the state does not take upon itself the responsibility of ensuring universal health protection. Thus a large portion of the population remains uninsured, which makes various interventions necessary for early diagnosis and treatment of diseases such as CRC.

The relationship between socioeconomic status and colon cancer is very well known in the literature. Regional differences in mortality rates for colon/rectum have been highlighted by different authors, pointing to the contribution of cultural and dietary habits, socioeconomic differences and lifestyle, for this heterogeneity, and other relevant aspects such as access health services, quality of care and hospital prevention services $^{(4,12,20)}$ as for colon cancer, specifically, we found that mortality rates for this cancer are higher in the South and southeast and smaller magnitudes of rates were found in the capitals of other Brazilian regions, which have lower socioeconomic status and higher concentration of rural areas ${ }^{(6)}$. Schottenfeld and Winawer ${ }^{(18)}$ and Muir and Nectoux ${ }^{(19)}$ noted that colon cancer is more common in populations most economically developed and which have Western living standards. Reis ${ }^{(27)}$, studying the relationship between colon cancer and socioeconomic integration in the city of São Paulo, noted that the area considered best insertion showed the highest rates of mortality due to colon cancer, when compared with others, in both sexes, and in almost all age groups. This author also found a gradient of increasing the magnitude of this mortality, statistically significant, toward better integration socioeconomic areas.

Many confounding factors may have accounted for the observation between income and mortality for colorectal cancer. Greater than $75 \%-95 \%$ of colon cancer occurs in people with little or no genetic risk ${ }^{(5,27)}$. Other risk factors include older age, male gender, high intake of fat, alcohol or red meat, obesity, smoking and a lack of physical exercise $^{(5,8,17,27)}$. Increased socio-economic indicators are most likely to be associated with known dietary risk factors such as red meat consumption. If this assumption is correctly assumed, it could have influenced only colorectal cancer incidence but not necessarily mortality. However, incidence data in Brazil are poor and sometimes even do not exist for some places or time periods. In fact, colorectal cancer mortality is probably related to late stage diagnosis. Instead, one could expect that improved socio-economic indicators would lead to increased early stage diagnosis and therefore decreased mortality.

In American and European context, it is possible to seek to relate the performance of screening for colorectal cancer to income of the individual, because different researchers have demonstrated the relationship between socioeconomic status and access to screening tests, showing the influence of various issues, such as age, education, preventive practices adopted by physicians, access to medical consultation, race, language spoken, etc. In Brazil, this screening is not established as a practice population and even individuals from more privileged classes do not usually realize it.

Ecological studies on adverse health effects of environmental exposure are increasingly common in the literature. In addition to the common drawbacks of an ecological epidemiology approach, important flaws regarding hypothesis formulation and exposure assessment can be observed in this study. According to this methodological design, ecologic studies are descriptive investigations - and not one of the approaches of the analytic epidemiology - that have been largely used to explore hypothesis on possible epidemiological associations towards the use of aggregate variables. As a whole, what these results seem to suggest is that despite inaccurate, the exposure indicator based on aggregate information on increasing income and wealthy are indeed able to discriminate regional differences in terms of pesticide exposure and subsequent health effects. In fact, they present the necessary requirements to be used in ecological studies, since a regression to the mean seems not to have been introduced in the studied outcome distributions. From a public health perspective, it is important to consider these variables as proxies from many conditions. The income 
does not interfere directly on the colorectal cancer, but can promote some conditions to decrease the exposure to risk factors such as diet (primary prevention) and to establish early diagnosis (secondary prevention).

\section{CONCLUSION}

The mortality rates for RAC over 9 years in Brazil has a strong relationship with the socioeconomic status of the population. The present study sought to establish the causal relationship between the increase in average household income per capita and mortality rates. It was noted that the TME followed from 2001 to 2009 the increase in family income. With this, we established a correlation between the socioeconomic status of the population and their living habits, which might be protective or risk factors for CRC.

In Brazil, in view of their development and increasing the income of its citizens, screening programs nationwide
CRC would be of great importance. However, there is a trace containing said organized series of interventions, from the identification of the target population to the appropriate follow-up of treated cases. There are basically opportunistic screening, treating the patient who somehow came to the health service. This delays the diagnosis, which makes therapeutic interventions and increases mortality by CRC.

If on one hand the CRC is one of the largest types of tumors and incidence accelerated in recent years, on the other is one of the cancers that most benefits from the strategies of primary and secondary prevention. Studies suggest that some changes in life habits would be able to prevent $66 \%$ to $75 \%$ of CRC ${ }^{(10)}$. Thus, it is necessary to discuss ways of tracking educational establishment of policies on population ${ }^{(24)}$, at least for subjects with higher risk potential for CRC, just as today it causes cancer of the cervix, breast and prostate, considering the emergence and growth trend of this topography in the area of oncology.

Guimarães RM, Rocha PGM, Muzi CD, Ramos RS. Incremento de renda e mortalidade por câncer colorretal no Brasil, 2001-2009. Arq Gastroenterol 2013;50(1):64-9

RESUMO - Contexto - Diversos estudos internacionais têm observado uma correlação entre a melhora dos indicadores sociodemográficos e as taxas de incidência e mortalidade por câncer de cólon e reto. Objetivo - O objetivo do presente estudo é estimar a correlação entre renda média per capita e a taxa de mortalidade por câncer colorretal no Brasil entre 2001 e 2009. Métodos - Obteve-se os dados de desigualdade de renda (índice de Gini), população que vive com baixa renda (inferir a 1/2 salário mínimo/mês), renda média familiar, PIB per capita e taxa de mortalidade por câncer de cólon e reto entre 2001 e 2009 através do DATASUS. A análise de tendência foi realizada através do método de regressão linear, e a correlação entre as variáveis através do coeficiente de correlação de Pearson. Resultados - Observou-se tendência ao declínio da pobreza e da desigualdade de renda, e incremento no PIB per capita e na renda média familiar e na taxa de mortalidade padronizada de câncer de cólon e reto no Brasil. Observou-se, ainda, correlação fortemente positiva entre a mortalidade por este sítio de câncer e desigualdade (homens $\mathrm{r}=-0,30, P=0,06$; mulheres $\mathrm{r}=-0,33, P$ $=0,05)$ de renda baixa renda(homens $\mathrm{r}=-0,80, P<0,001$; mulheres $\mathrm{r}=-0,76, P<0,001$ ), renda média familiar (homens $\mathrm{r}=0,79$, $\mathrm{p}=0,06$; mulheres $\mathrm{r}$ $=0,76, P<0,001$ ) e PIB per capita (homens $\mathrm{r}=0,73, P<0,001$; mulheres $\mathrm{r}=0,68, P<0,001$ ) em todo o período estudado. Conclusão - $\mathrm{O}$ incremento da renda e a redução da desigualdade podem parcialmente explicar o aumento da ocorrência do câncer de cólon e reto e isso possivelmente se deve ao acesso diferenciado a alimentos reconhecidos como fator de risco, como carne vermelha e os ricos em gordura. É importante, portanto, avaliar como prioridade dos programas de saúde pública a abordagem nutricional em países de economia intermediária, como é o caso do Brasil.

DESCRITORES - Neoplasias colorretais, mortalidade. Pobreza. 


\section{REFERENCES}

1. Aarts MJ, Lemmens VE, Louwman MW, Kunst AE, Coebergh JW. Socioeconomic status and changing inequalities in colorectal cancer? A review of the associations with risk, treatment and outcome. Eur J Cancer. 2010;46(15):2681-95.

2. Brasil. Ministério da Saúde, Secretaria de Assistência à Saúde, Instituto Nacional do Câncer. Falando sobre câncer do intestino. Rio de Janeiro: INCA; 2003. Available from: http://pt.scribd.com/doc/40853678/Cancer-de-Intestino-INCA

3. Brasil. Ministério da Saúde. DATASUS 2012. [Internet]. [cited 2012 May 4] Available from: www.datasus.gov.br.

4. Castro JS, Marina FF, Martìnez ES, Ponce ECL. Panorama epidemiológico de la mortalidad por cáncer en el Instituto Mexicano del Seguro Social: 1991-1995. Salud Pública Mex 1997;39:266-73.

5. Cunningham D, Atkin W, Lenz HJ, Lynch HT, Minsky B, Nordlinger B, Starling N. Colorectal cancer. Lancet. 2010;375(9719):1030-47.

6. das Neves FJ, Mattos IE, Koifman RJ. [Colon and rectal cancer mortality in Brazilian capitals, 1980-1997]. Arq Gastroenterol. 2005;42(1):63-70

7. Doll R, Waterhouse J, Payne P. Cancer incidence in five continents: a technical report. Berlin: International Agency for Research on Cancer; 1966.

8. Fedirko V, Tramacere I, Bagnardi V, Rota M, Scotti L, Islami F, Negri E, Straif K, Romieu I, La Vecchia C, Boffetta P, Jenab M. Alcohol drinking and colorectal cancer risk: an overall and dose-response meta-analysis of published studies. Ann Oncol. 2011;22(9):1958-72.

9. Ferlay J, Shin HR, Bray F, Forman D, Mathers C, Parkin DM. GLOBOCAN 2008, Cancer Incidence and Mortality Worldwide: IARC CancerBase No. 10 [Internet]. Lyon, France: International Agency for Research on Cancer; 2011. Available from: http://globocan.iarc.fr

10. Giovannucci E. Modifiable risk factors for colon cancer. Gastroenterol Clin North Am 2002; 31:925-943.

11. Guerra MR, Gallo CVM, Azevedo G, Mendonça S. Risco de câncer no Brasil: tendências e estudos epidemiológicos mais recentes. Rev Bras Cancerol. 2005;51:227-34.

12. Horm JW, Devesa SS, Burhansstipanov L. Cancer incidence, mortality, and survival among racial and ethnic minority groups in the united. In: Schottenfeld D, Fraumeni JF Jr, editors. Cancer epidemiology and prevention. Oxford University Press; 1996. p.192-235.

13. INCA. Estimativa 2012. Incidência de Câncer no Brasil. [Internet]. [cited 2012 Jun 19]. Avalaible from: <www.inca.gov.br/estimativa/2010>.

14. Jemal A, Siegel R, Ward E, Murray T, Xu J, Thun MJ. Cancer statistics, 2007. CA Cancer J Clin. 2007;57:43-66.
15. Kelsall HL, Baglietto L, Muller D, Haydon AM, English DR, Giles GG. The effect of socioeconomic status on survival from colorectal cancer in the Melbourne Collaborative Cohort Study. Soc Sci Med. 2009;68(2):290-7.

16. Latorre MRDO, Cardoso MRA. Análise de séries temporais em epidemiologia: uma introdução sobre os aspectos metodológicos. Rev Bras Epidemiol. 2001;4(3):145-52.

17. Lee IM, Shiroma EJ, Lobelo F, Puska P, Blair SN, Katzmarzyk PT; Lancet Physical Activity Series Working Group. Effect of physical inactivity on major non-communicable diseases worldwide: an analysis of burden of disease and life expectancy. Lancet. 2012;380(9838):219-29.

18. Muir CS, Nectoux J. International patterns of cancer. In: Schottenfeld D, Fraumeni JF Jr, editors. Cancer epidemiology and prevention. London: Oxford University Press; 1996. p.141-67.

19. Reis DO. Diferenças socioeconômicas na mortalidade por neoplasias malignas no Município de São Paulo [dissertation]. São Paulo: Faculdade de Saúde Pública da Universidade de São Paulo; 1997.

20. Schottenfeld D, Winawer SJ. Cancers of large intestine. In: Schottenfeld D Fraumeni JF Jr, editors. Cancer epidemiology and prevention. London: Oxford University Press; 1996. p.813-40.

21. Segi M, Fujisaku S, Kurihara M, Narai Y, Sasajima K. The age-adjusted death rates for malignant neoplasms in some selected sites in 23 countries in 1954-1955 and their geographical correlation. Tohoku J Exp Med. 1960;72:91-103.

22. Tavani A, Fioretti F, Franceschi S, Gallus S, Negri E, Montella M, Conti E, La Vecchia C. Education, socioeconomic status and risk of cancer of the colon and rectum. Int J Epidemiol. 1999;28(3):380-5.

23. Valadão M, Castro LS. Câncer colo-retal hereditário. Rev Col Bras Cir 2007; 34:193-200.

24. Valadão M, Leal RA, Barbosa LC, Carneiro M, Muharre RJ. Perfil dos pacientes portadores de câncer colorretal operados em um hospital geral: necessitamos de um programa de rastreamento acessível e efetivo. Rev Bras Coloproctol. 2010;30:160-6

25. van Loon AJ, van den Brandt PA, Golbohm RA. Socioeconomic status and colon cancer incidence: a prospective cohort study. Br J Cancer. 1995;71(4):882-7.

26. Vasques ALR, Peres MA. Tendência temporal da mortalidade por câncer de cólon e reto em Santa Catarina no período entre 1980 a 2006. Epidemiol. Serv. Saúde. 2010;19(2):91-100

27. Watson AJ, Collins, PD (2011). Colon cancer: a civilization disorder. Dig Dis. 2011;29(2):222-8.

Received 4/1/2013. Accepted 30/1/2013 